\title{
VEGETATIVNO RAZMNOŽAVANJE PITOMOG KESTENA I MARUNA
}

\section{VEGETATIVE PROPAGATION OF SWEET CHESTNUT AND MARRONS}

\author{
Katarina TUMPA ${ }^{1}$, Marilena IDŽOJTIĆ ${ }^{1}$, Mirna ĆURKOVIĆ-PERICA², Marin JEŽIĆ ${ }^{2}$, Davor JURETIĆ ${ }^{3}$, \\ Damir DRVODELIĆ ${ }^{4}$, Mario ŠANGO ${ }^{4}$, Milovan ŽIGANTE ${ }^{5}$, Igor POLJAK ${ }^{*}$
}

\begin{abstract}
SAŽETAK
Maruni su selekcionirane sorte europskog pitomog kestena, uzgajane radi krupnoće i kvalitete plodova. Većina zemalja u kojima raste europski pitomi kesten ima svoje autohtone sorte, koje su dobivene dugotrajnom selekcijom i uzgojem, tijekom više stoljeća. Kultiviranje maruna ima dugu povijest u zapadnoj Hrvatskoj, većinom na području Lovrana i okolice. Nažalost, stabla maruna ugrožena su štetnicima i bolestima, kao i napuštanjem nasada, no dio uzgajivača i dalje njeguje tradicionalan način uzgoja. U ovome se radu daje pregled najčešćih metoda vegetativnog razmnožavanja pitomog kestena i maruna, kao i kraći pregled načina uzgoja, razmnožavanja te značaja nasada maruna u Hrvatskoj. Budući da je prenošenje istovjetnih karakteristika plodova s matične biljke na potomstvo moguće jedino izravnim prenošenjem genotipa roditeljske biljke, maruni se mogu razmnožavati samo vegetativnim metodama. Najčešća metoda vegetativnog razmnožavanja maruna, kao i pitomog kestena, u rasadnicima je cijepljenje. Ostale korištene metode vegetativnog razmnožavanja su razmnožavanje povaljenicama, reznicama i kulturom tkiva.
\end{abstract}

KLJUČNE RIJEČl: vegetativno razmnožavanje, cijepljenje, maruni, pitomi kesten, kultivari

\section{UVOD}

\section{INTRODUCTION}

Rod Castanea Mill. obuhvaća vrste umjerenog pojasa Azije, Europe te istočnoga dijela SAD-a. Broj vrsta razlikuje se $s$ obzirom na različite klasifikacije, no gospodarski najznačajnije vrste su europski pitomi kesten (Castanea sativa Mill.), japanski pitomi kesten (C. crenata Sieb. et Zucc.), kineski pitomi kesten (C. mollissima Blume) i američki pi- tomi kesten (C. dentata (Marshall) Borkh.). Navedene vrste značajne su od davnina zbog kvalitetnog drva i jestivih, vrlo hranjivih plodova (Johnson 1988; Lang i sur. 2006; Corredoira i sur. 2017).

Europski pitomi kesten jedina je europska vrsta roda $\mathrm{Ca}$ stanea. Raste kao stablo visine do $30 \mathrm{~m}$. Stabla na osami kratkog su debla i široko razgranate kuglaste krošnje s nekoliko osnovnih i nepravilno raspoređenih debelih grana

\footnotetext{
${ }^{1}$ Katarina Tumpa, mag. ing. silv., prof. dr. sc. Marilena Idžojtić, doc. dr. sc. Igor Poljak, Sveučilište u Zagrebu, Fakultet šumarstva i drvne tehnologije, Zavod za šumarsku genetiku, dendrologiju i botaniku, Svetošimunska cesta 23, 10000 Zagreb

${ }^{2}$ prof. dr. sc. Mirna Ćurković-Perica, doc. dr. sc. Marin Ježić, Sveučilište u Zagrebu, Prirodoslovno-matematički fakultet, Zavod za mikrobiologiju, Marulićev trg 9a, 10000 Zagreb

${ }^{3}$ Davor Juretić, Kestenici Juretić, Kalvarija 10/1, 47000 Karlovac

${ }^{4}$ izv. prof. dr. sc. Damir Drvodelić, Mario Šango, mag. ing. silv., Sveučilište u Zagrebu, Fakultet šumarstva i drvne tehnologije, Zavod za ekologiju i uzgajanje šuma, Svetošimunska cesta 23, 10000 Zagreb

${ }^{5}$ Milovan Žigante, Nova cesta 82, 51410 Opatija

*Korespondencija: doc. dr. sc. Igor Poljak, ipoljak@sumfak.hr
} 
(Herman 1971; Poljak 2014). U šumskom sklopu stabla su dugačkog i ravnog debla te razmjerno malene krošnje. Pitomi je kesten jednodomna vrsta s jednospolnim cvjetovima (Idžojtić 2013). Soliterna stabla počinju plodonositi u dobi od 6 do 12 godina, dok će ona u sastojini prve plodove dati nešto kasnije. Cvjetanje je u lipnju, nakon listanja. Plodovi su orasi (kesteni), a najčešće je po tri ploda smješteno unutar jedne bodljikave kupule (ježice), koja se dozrijevanjem u listopadu raspucava na četiri jednaka dijela (Idžojtić 2013). Svaki plod, odnosno kesten, sadrži po jednu do dvije sjemenke. Plodove rasprostranjuju životinje (zoohorija).

Osim stabala u šumskim sastojinama brežuljkasto-brdskog pojasa kontinentalne Hrvatske, Istre te na otocima Cresu i Krku (Medak i sur. 2009) na području Istre i Kvarnera prisutna su i kultivirana stabla, poznata pod nazivom maruni. Maruni su selekcionirane sorte (kultivari) europskog pitomog kestena, uzgajane radi krupnoće i kvalitete plodova (Idžojtić i sur. 2012; Poljak i sur. 2016, 2021). Prema talijanskim standardima maruni su samo one sorte europskog pitomog kestena s najkvalitetnijim, ukusnim, krupnim plodovima duguljastog oblika, malim hilumom, svjetlije smeđe boje, malo izbočenim, uzdužnim, tamnim prugama, koji se lako ljušte i rijetko imaju dvostruke sjemenke (Bounous 2002; Mellano i sur. 2012). Francuska definicija maruna slična je prethodnoj, a naznačeno je da moraju imati manje od $12 \%$ plodova s dvije sjemenke (Bounous 2002). Osim maruna, posljednjih desetak godina u uzgoju su sve zastupljeniji križanci europskog i japanskog pitomog kestena (slika 1), koji imaju veći prinos i krupnije plodove (Breisch 1995; Idžojtić i sur. 2012; Laratta i sur. 2016; Poljak i sur. 2016, 2021). Prema iskustvima hrvatskih uzgajivača, otpornost spomenutih hibrida na patogene i napade štetnika je malo bolja u odnosu na tradicionalne sorte pitomog kestena.

\section{METODE VEGETATIVNOG RAZMNOŽAVANJA VEGETATIVE PROPAGATION METHODS}

S obzirom na kasnu fruktifikaciju, kao i varijabilnost generativno dobivenih biljaka (uzgojenih iz sjemena), u komercijalnome uzgoju pitomog kestena primjenjuju se metode vegetativnog razmnožavanja. Za razliku od biljaka uzgojenih iz sjemena, vegetativno razmnožavanje omogućuje uzgoj velikog broja istovjetnih biljaka, čime je osiguran urod plodova uniformnih značajki. Najčešće korištene metode su cijepljenje, razmnožavanje povaljenicama i reznicama (makropropagacijske metode) te razmnožavanje kulturom tkiva in vitro (mikropropagacija) (Bounous i Beccaro 2002).

\section{Cijepljenje - Grafting}

Cijepljenje je metoda heterovegetativnog razmnožavanja kojom dolazi do spajanja dijelova genski različitih biljnih organizama, uz povezivanje njihovih provodnih tkiva (žila). Kao rezultat nastaje jedan funkcionalan organizam, sastav- ljen od dviju jedinki. Cijepljenje se provodi spajanjem plemke na podlogu. Plemka je izbojak ili djelić kore s pupom biljke koju želimo razmnožiti, a koja će tvoriti većinu nadzemnog dijela novonastalog organizma, dok podloga, koja se na mjestu cijepa spaja s plemkom, služi kao korijenski sustav novoga organizma (Rothenberger i Starbuck 2008; Bilderback i sur. 2014).

Cijepljenje je brz i učinkovit način za postizanje brojnih hortikulturnih ciljeva: 1. izbjegavanje problema juvenilnosti - velik broj biljaka uzgojenih iz sjemena ne započinje s cvjetanjem, odnosno plodonošenjem dulji niz godina; cijepljenjem novonastala biljka zadržava dob biljke s koje je uzeta plemka te "preskače" dugo razdoblje sazrijevanja; 2. očuvanje genotipa ozlijeđene biljke - u slučaju truleži ili oštećenja korijena i/ili debla, uzimanjem plemke s postojećeg stabla i ucijepljivanjem u novu podlogu moguće je spasiti ozlijeđenu biljku, odnosno očuvati genotip (kultivar); 3. cijepljenjem je također moguće popraviti oštećenja kore te povezati nestabilne grane; 4 . kontrola dimenzija biljke određene podloge mogu uzrokovati patuljasti rast plemke te time osigurati željene dimenzije konačnog stabla (npr. voćkarice); 5. otpornost na stresne čimbenike - odabir podloge otporne na patogene $\mathrm{i} /$ ili negativne okolišne čimbenike osigurava uspješan rast biljke.

Uspješnost cijepljenja ovisi o većem broju čimbenika, no najvažnija je svakako genska kompatibilnost plemke i podloge (Mudge i sur. 2009). Osim toga, na uspješnost cijepljenja utjecat će i odabrani način cijepljenja, starost plemke, vrijeme cijepljenja te okolišni uvjeti (Singh i Rehman 2019). Taksonomska srodnost biljaka glavni je preduvjet uspješnosti ove metode, a postotak uspješno cijepljenih biljaka je manji što su one genski različitije (manje srodne). Općenito može se reći kako će spajanje biti uspješno između podloge i plemke istoga genotipa ili vrste, a rijetko ako je razlika na razini roda ili porodice. Cijepljenje biljaka između različitih porodica u praksi je najčešće nemoguće. Ova generalizacija podliježe iznimkama, budući da je kompatibilnost biljaka vrlo varijabilna na svim razinama srodnosti (Mudge i sur. 2009).

Cijepljenje pitomog kestena uspješnija je metoda razmnožavanja od propagacije povaljenicama ili zakorijenjivanja reznica (Clapper 1954) te se općenito smatra najuspješnijom metodom makropropagacije (Nelson i sur. 2014). Osim toga, odlikuje se uspješnošću koja omogućava isplativu proizvodnju maruna (Oraguzie i sur. 1999).

\section{Tehnike cijepljenja pitomog kestena i maruna - Grafting techniques for sweet chestnut and marrons}

Postoje različite tehnike cijepljenja (slika 2), a svaki rasadničar će se opredijeliti za jednu ili dvije koje mu najviše odgovaraju, uzimajući u obzir uspješnost i vrijeme potrebno za provođenje postupka. Najčešće korištene tehnike 


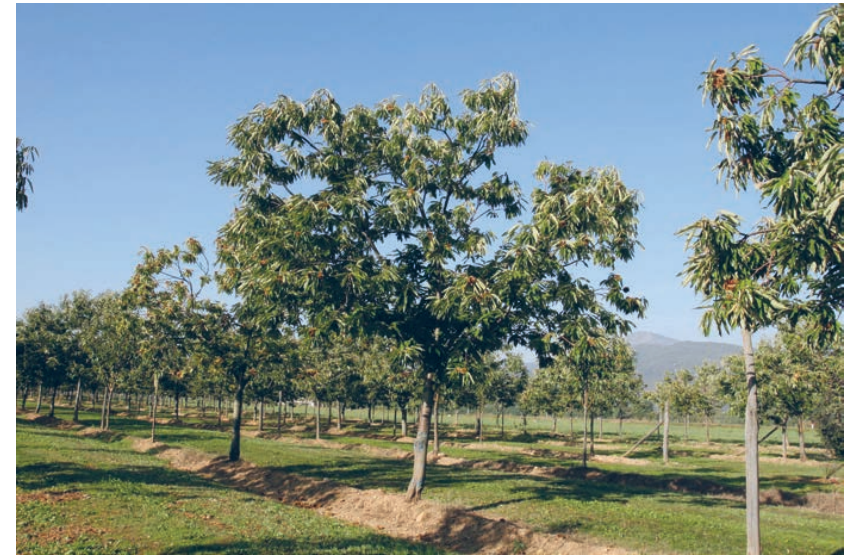

Slika 1. Plantaža euro-japanskih hibrida pitomog kestena.

Figure 1 Chestnut plantation with Euro-Japanese hybrids.

cijepljenja su prema Keysu (1978), Pereira-Lorenzo i Fernandez-Lopez (1997), Serdar i Soylu (2005) i Mayfieldu (2009):

A) Cijepljenje na spoj ili obično spajanje (splice) - podloga i plemka odrezane su dijagonalno te se prislanjaju pazeći na dodirivanje kambijalnih slojeva; ako je podloga deblja od plemke, podloga se najprije reže vodoravno te zatim dijagonalno, kako bi se postiglo spajanje što većega dijela kambijalnih zona.

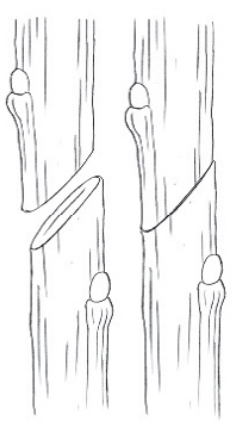

cijepljenje na spoj ili obično spajanje (splice graft)

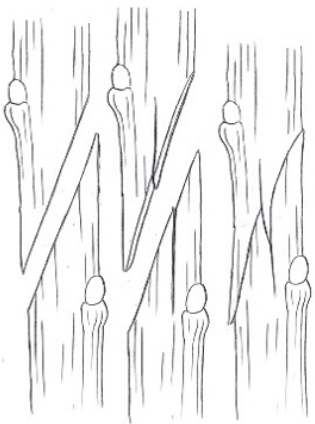

cijepljenje na engleski spoj (whip graft)
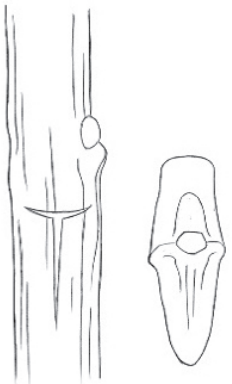

okuliranje T-rezom (T-budding)

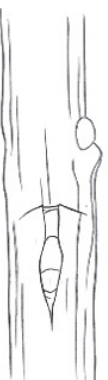

B) Cijepljenje na engleski spoj (whip) - podloga i plemka režu se dijagonalno te se na tim rezovima dodaju komplementarni zarezi (jezičci), pomoću kojih se plemka čvršće uglavljuje na podlogu.

C) Cijepljenje u raskol (cleft) - sredinom podloge urezuje se okomiti rez, u koji se umeće klinasto odrezana plemka.

D) Postrano ili bočno cijepljenje (side) - na podlozi se s bočne strane urezuje dijagonalan rez, prema središtu stabljike (izbojka) te se u tako nastao utor umeće klinasto odrezana plemka, pazeći pritom da se kambijalni slojevi dodiruju.

E) Okuliranje T-rezom (T-okuliranje) i obrnutim T-rezom - na kori podloge vodoravnim te okomitim rezom stvara se pukotina uspravnog ili preokrenutog oblika slova “T”, u koju se umeće pup plemke. Pupovi trebaju biti posve razvijeni i dormantni, a okuliranje se vrši ljeti, kako bi mjesto cijepa stiglo srasti do zime.

F) Pločasto okuliranje (chip) - s podloge se uklanja "pločica" zrele kore do kambijalnog sloja; na ovo se mjesto stavlja "pločica" kore plemke s pupom te se kambijalni slojevi pažljivo namještaju (Bilderback i sur. 2014).

G) Cijepljenje na prozor (patch) - s podloge se uklanja veći kvadrat kore i kambijalnog sloja te se na njegovo mjesto

ilustratorica: Marija Ana Turčić

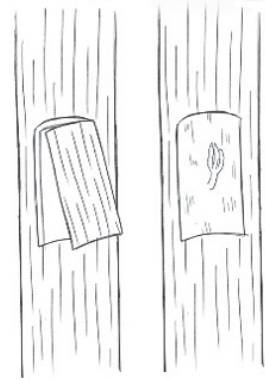

cijepljenje na prozor (patch-budding)
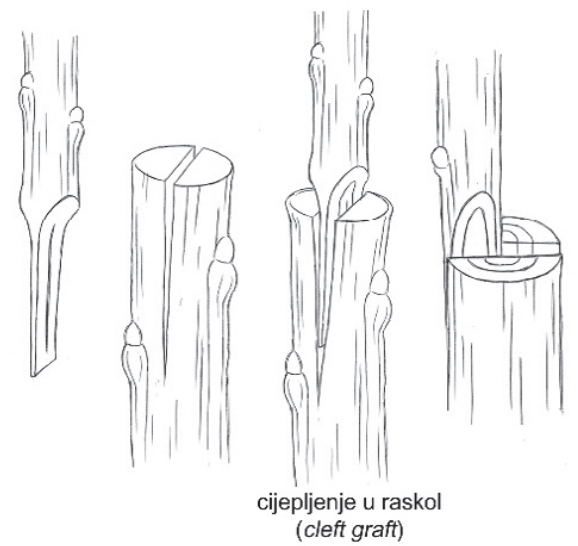

Slika 2. Načini cijepljenja pitomog kestena (autorica Marija Ana Turčić).

Figure 2 Sweet chestnut grafting techniques (author Marija Ana Turčić). 

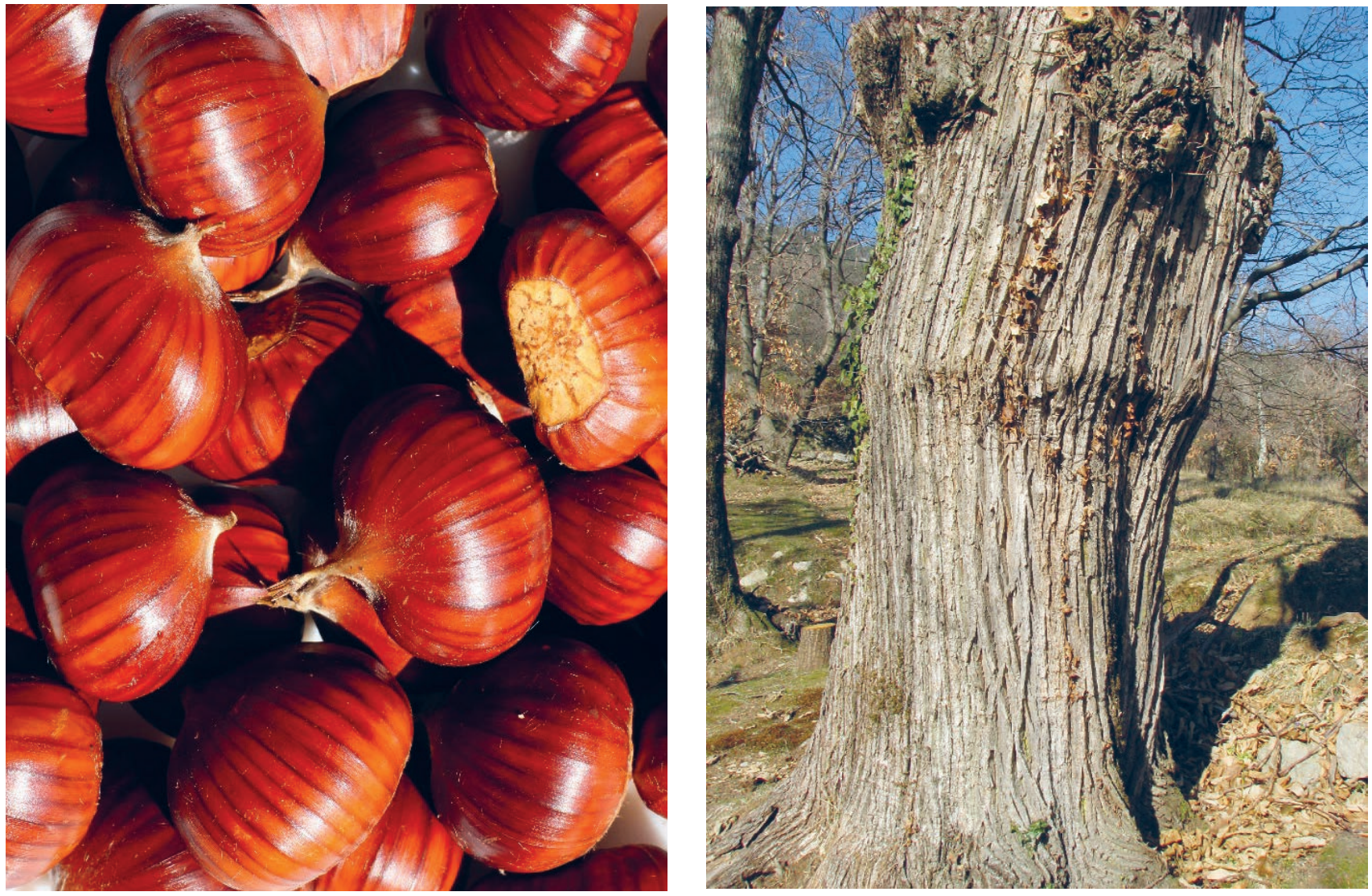

Slika 3. Lovranski marun: (A) plodovi; (B) spoj između podloge i plemke.

Figure 3 Lovran marron: (A) fruits; (B) graft union between rootstock and scion.

stavlja komplementaran kvadrat kore s kambijem plemke, koji na sebi ima pup. Ova je metoda primjerena u slučaju već odebljale kore starijih izbojaka, kada su pločasto okuliranje i T-okuliranje neizvedivi (Carroll 2017).

Cijepljenje na spoj najjednostavniji je, a prema Keysu (1978) i najuspješniji način cijepljenja pitomog kestena. Perreira-Lorenzo i Fernandez-Lopez u svome istraživanju iz 1997. godine utvrdili su da je cijepljenje na prozor najuspješniji način cijepljenja križanaca europskog i azijskih pitomih kestena, dok su Serdar i Soylu (2005) zaključili kako se turski kultivari pitomog kestena najuspješnije cijepe obrnutim T-rezom ili cijepljenjem na engleski spoj. Pločasto okuliranje te cijepljenje na spoj pokazali su se najboljim načinima cijepljenja američkog pitomog kestena, uz uspješnost do čak 100 \% (Mayfield 2009).

Nakon samog spajanja plemke i podloge, mjesto cijepa se omata čistom, plastičnom vezicom, odnosno elastičnom folijom (stretch folija), pazeći pritom da pup ostaje nepokriven. Zarastanje rane, odnosno srastanje kambijalnih slojeva plemke i podloge, brže je ako su njihove dodirne površine veće (Maltoni i sur. 2001). Nakon cijepljenja, mjesto cijepa potrebno je premazati voćarskim voskom, a prije cijepljenja alat za cijepljenje sterilizirati. Mjesto cijepa po- trebno je redovito pregledavati. Nakon mjesec dana, kambijalni slojevi trebali bi srasti te je potrebno skinuti vezicu, pazeći pritom da se ne ošteti mjesto spoja. Ako je spoj dobro kalusirao te su plemka i podloga srasle, ponovno omatanje elastičnom folijom nije potrebno. Sve pupove i izdanke iz panja podloge potrebno je ukloniti, a ovaj se postupak ponavlja barem još jednom prije sušnog razdoblja ljeti, čime se poboljšava rast plemke. Ako je rast plemke prebrz, moguće je odrezati njezin vrh i time usporiti rast (Maltoni i sur. 2001).

Za pravilno cijepljenje bitno je plemku uzeti u optimalno doba godine, kao i odabrati plemku dobre starosti, odnosno zrelosti tkiva. Prema Bilderbacku i sur. (2014), optimalni mjeseci za uzimanje plemki pitomog kestena su veljača i ožujak. Plemke trebaju biti tridesetak centimetara duge, a nakon sakupljanja potrebno ih je držati u gotovo suhome tresetu ili u dobro zatvorenim plastičnim vrećicama, na temperaturi od oko $1-2{ }^{\circ} \mathrm{C}$. U većemu je broju istraživanja (Galic i sur. 2014; Nelson i sur. 2014) utvrđeno kako se plemke sakupljane s izdanaka iz panjeva te mlađih stabala uspješnije spajaju s podlogama u odnosu na izbojke sa starijih stabala. Glavni razlog koji dovodi do problema sa spajanjem te srastanjem kambijalnih slojeva na mjestu cijepa nakupljanje je tvari koje neutraliziraju učinak biljnog hormona indol-3-octene kiseline (IAA od eng. indole-3-ace- 


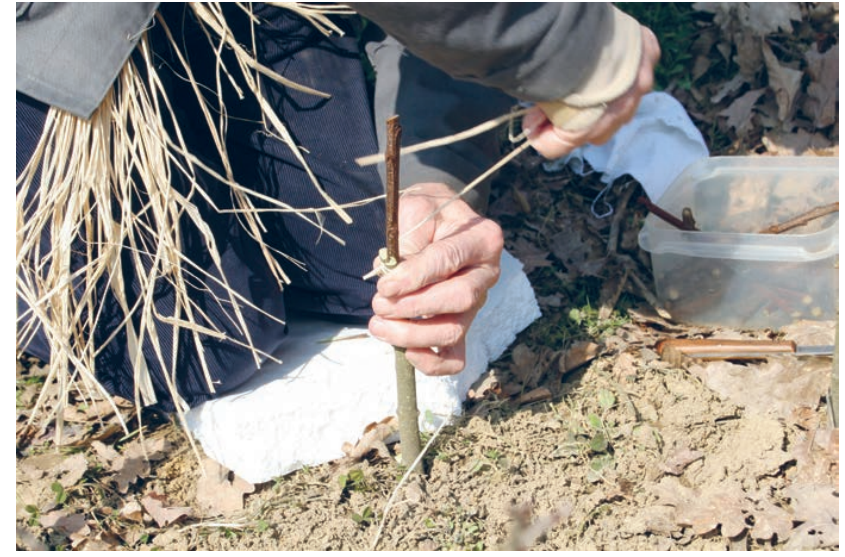

Slika 4. Cijepljenje u raskol.

Figure 4 Cleft graft.

tic acid). Osim pravilno izvedenog cijepljenja, velik je utjecaj pravilne njege te uzgoja cijepljenih biljaka. Niske temperature usporavaju kalusiranje spoja cijepa te oslabljuju ili umanjuju uspješnost primanja plemke na podlogu. Također, utvrđena je razlika u uspješnosti pojedine tehnike cijepljenja turskih kultivara europskog pitomog kestena na hibridne podloge, ovisno o načinu uzgoja sadnica (Serdar i Soylu 2005). Prilikom uzgoja na otvorenome polju, uspješnijim se pokazalo cijepljenje na engleski spoj, dok je u biljaka uzgajanih u kontejnerima veći uspjeh postignut Tokuliranjem. Odabir pravilnog načina uzgoja stoga ovisi o proizvodnome planu - biljke uzgajane u kontejnerima imaju veći uspjeh u prilagodbi nakon presadnje, no spremne su za prodaju tek u trećoj uzgojnoj godini. Biljke uzgajane na otvorenome u prodaju mogu već najesen, ako su cijepljene u proljeće.

Osim cijepljenja plemke na izbojak podloge, u sjevernoameričkom šumarstvu uobičajeno je i cijepljenje u sjeme (nut grafting). Ovaj način relativno je jednostavan i jeftiniji je od okuliranja, no nije primjenjiv za cijepljenje velikog broja biljaka. Razvijen je u SAD-u, gdje se aktivno koristi u svrhu očuvanja američkog pitomog kestena, značajno oštećenog pojavom tintne bolesti (Phytophthora spp.) početkom 20. stoljeća (Mayfield 2009). Podloga za cijepljenje, sjeme, je pitomi kesten iste vrste kao i plemka. Nakon klijanja i pojave hipokotila, izbojak se razreže te se time uklanjaju hipokotil i radikula. Pomoću noža, između supki se umeće klinasto oblikovana plemka. Prema Mooreu (1963), početna uspješnost spajanja plemke s podlogom iznosi 60$80 \%$, no uspješnost zakorjenjivanja značajno opada s vremenom te preživljenje nakon dva tjedna iznosi $38 \%$. Prema Mayfieldu (2009) dugoročno preživljavanje iznosi 10-25\%. Sličan način naziva se cijepljenje na negativno geotropnu radikulu, a razvijen je 1968. godine za primjenu na japanskom pitomom kestenu. I u ovome se slučaju sjeme pušta da proklije, no vrh radikule uklanja se prije pojave korjenčića i probijanja epikotila. Radikula se razrezuje te se u tako nastao utor umeće plemka. Ovaj je način nešto kompliciraniji od klasičnog cijepljenja u sjeme, no zabilježeno je preživljenje od gotovo $100 \%$ u stakleničkim pokusima (Keys 1978).

\section{Razmnožavanje povaljenicama - Propagation by layering}

Razmnožavanje povaljenicama (polijeganje) podrazumijeva zakorjenjivanje izbojaka matične biljke te naknadno odsijecanje ukorijenjenog izbojaka od matične biljke (Clapper 1954). Tri su najčešća načina polijeganja: 1. obično (lučno) polijeganje - najjednostavniji i ujedno najčešći način polijeganja primjenjiv na velikome broju vrsta; 2 . polijeganje u jarak (kontinuirano ili kinesko polijeganje); 3. složeno polijeganje (zmijoliko ili valovito). Prednost polijeganja očituje se u jednostavnoj primjeni te većem broju dobivenih biljaka, no metoda nije primjenjiva za sve vrste.

Polijeganje kao metodu razmnožavanja pitomog kestena često primjenjuju francuski uzgajivači. Međutim, rezultati istraživanja na povaljenicama značajno se razlikuju. U istraživanju Landalucea (1952) nije postignut dobar uspjeh u zakorijenjivanju povaljenica na mladim biljkama, dok su izbojci starijih panjeva imali uspješnost zakorjenjivanja od samo $20 \%$. Pri tomu se primjena auksina nije pokazala uspješnom, dok je prstenovanje kore vremenski i tehnički vrlo zahtjevno. U kasnijem istraživanju iz 1953. godine (Vietiez 1953), zabilježen je uspjeh u razmnožavanju povaljenicama. $U 15$ različitih tretiranja, uspješnost zakorjenjivanja bila je različita, a najuspješnijim su se pokazala tri tretmana: $5 \mathrm{mg} / \mathrm{g}$ indol-3-maslačne kiseline (IBA od eng. indole3-butyric acid) i $5 \mathrm{mg} / \mathrm{g}$ IAA; $10 \mathrm{mg} / \mathrm{g}$ IBA; $4 \mathrm{mg} / \mathrm{g}$ IAA i 4 $\mathrm{mg} / \mathrm{g}$ 2,4-diklorofenoksioctene kiseline (2,4-D od eng. 2,4-dichlorophenoxyacetic acid). Postupak je proveden u proljeće, uz primjenu auksina u lanolinskoj pasti te uz prekrivanje grana vlažnim mahom tresetarom. Korijen koji se razvio bio je najčešće debeo i bez korjenovih dlačica i time

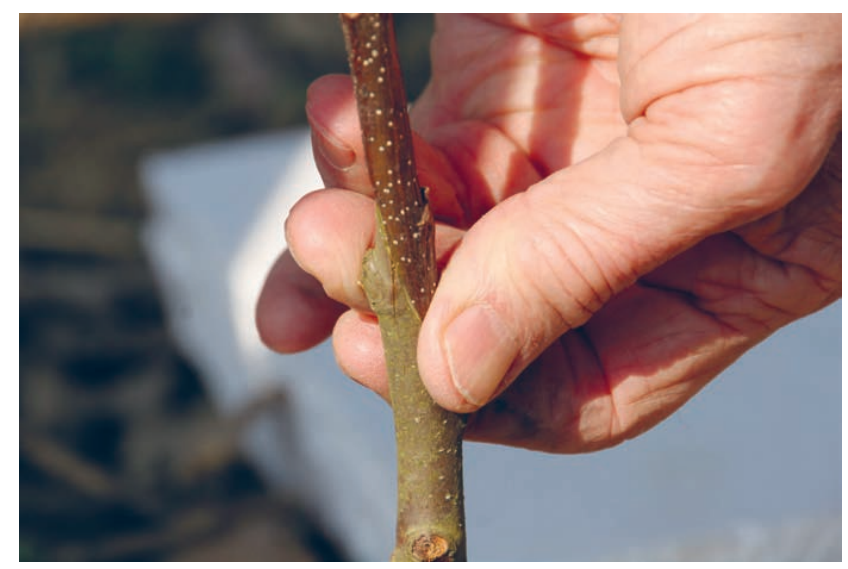

Slika 5. Cijepljenje na engleski spoj.

Figure 5 Whip graft. 
uglavnom neprimjenjiv za presadnju. Najbolje rezultate postigli su Vietiezi sur. (1955). U njihovome istraživanju također su primijenjeni auksini u lanolinskoj pasti, u različitim koncentracijama, kao i prekrivanje tresetom te tlom. Najbolje rezultate razvoja korijena postigli su izbojci iz panja, u svim koncentracijama auksina. Vlaknasti korijen razvio se u 100 \% biljaka tretiranih s 12 mg/g IBA. Najveći izazov prilikom razmnožavanja povaljenicama, kao i cijepljenjem, velik je broj radnih sati potrebnih za obavljanje razmnožavanja. Osim toga, potreban je velik broj matičnih biljaka za dobivanje dovoljnog broja klonova. Odumiranje prilikom presadnje također je značajno (Keys 1978).

Polijeganju sličan način razmnožavanja je i nagrtanje, odnosno razmnožavanje grebenicama. Obično se primjenjuje u proizvodnji podloga za voćkarice. U proljeće se nadzemni dio biljke reže na $3 \mathrm{~cm}$ od tla, izbojci se povezuju žicom te nagrću zemljom. Ujesen tlo se uklanja, a iz adventivnih pupova tijekom vegetacijske sezone razvija se veći broj izbojaka. Ovaj je postupak složen te ga često primjenjuju francuski uzgajivači. Prednost ove metode je što se od jedne matične biljke, u slučaju nekih voćkarica, može dobiti i do 12 zakorijenjenih izbojaka, dok se jedna biljka, uz odgovarajuću njegu može koristiti za razmnožavanje do 20 godina (Benković-Lačić 2013). Nagrtanje pitomog kestena opisuju i Singh i Rehman (2019). U njihovome istraživanju, europski pitomi kesten razmnožavan ovom metodom, davao je do $90 \%$ zakorjenjenih izbojaka uz primjenu IBA i ozljeđivanje matične biljke žicom.

\section{Razmnožavanje reznicama - Propagation by cuttings}

Razmnožavanje reznicama, podrazumijeva uzgoj nove jedinke zakorjenjivanjem dijela matične biljke, najčešće lista, odrezane stabljike ili korijena. Osim zdravstvenog stanja biljnog materijala, prilikom zakorjenjivanja značajnu ulogu imaju supstrat za zakorjenjivanje, vlažnost supstrata, svjetlost, prisutnost hranjiva i hormona za zakorjenjivanje. Osnovna zadaća supstrata je osigurati čisto, po mogućnosti sterilno, okruženje za razvoj korijena, kao i dobru drenažu viška vode. Reznice je potrebno pikirati i staviti na dobro osvjetljeni položaj, osim u slučaju korijenskih reznica, koje se zakorjenjuju u mraku. Većina se reznica ne prihranjuje u početnim fazama uzgoja, dok je primjena hormona za zakorjenjivanje moguća i poželjna u nekih vrsta (Relf i Ball 2009).

Pitomi kesteni se teško zakorjenjuju, za što je odgovorno više razloga. U istraživanju iz 1964. godine (Vietiez i sur. 1964), utvrđeno je da C. sativa i C. mollissima sadrže vrlo malo ili nimalo IAA, hormona koji stimulira razvoj adventivnih korjenčića. Osim toga, C. sativa sadrži organske kiseline koje vjerojatno inhibiraju zakorjenjivanje (Clapper 1954). Budući da se koncentracija IAA smanjuje starenjem tkiva, mlađe reznice (zelene) će se lakše zakorjeniti. Izbojci iz panja također se dobro zakorjenjuju (Galic i sur. 2014). Zakorjenjivanje se dodatno može potaknuti ispiranjem inhibitornih tvari iz reznica prije zakorjenjivanja držanjem u tekućoj vodi šest mjeseci; ovaj postupak dakako usporava proces i nije pogodan za masovnu proizvodnju (Clapper 1954). Osim unutarnjih, na zakorjenjivanje utječu i okolišni čimbenici, koje je lakše kontrolirati. Pritom je posebno važno kontrolirati i minimalizirati isušivanje te osigurati optimalnu temperaturu (Galic i sur. 2014). U istraživanju iz 1992. godine, usprkos uspješnom zakorjenjivanju, reznice su odumrle u fazi presadnje zbog isušivanja lišća te truleži osnove reznice (Fernandez-Lopez i sur. 1992).

\section{Mikropropagacija pitomog kestena - Chestnut micropropagation}

Gore navedene metode makropropagacije skupe su, ograničene učinkovitosti te zahtijevaju dulje proizvodne cikluse. Uzgoj kulture tkiva, odnosno razmnožavanje in vitro, omogućava proizvodnju superiornih klonova za proizvodnju drva i/ili plodova, kao i uzgoj jedinki otpornih na bolesti i napadaje štetnika. Osim toga, mikropropagacija je učinkovit način očuvanja ugroženih genotipova metodom ex situ. Kada je riječ o pitomom kestenu, metode mikropropagacije koje se primjenjuju su diferencijacija adventivnih pupova, somatska embriogeneza te, kao najčešća metoda koja će ovdje biti i opisana, proliferacija postranih pupova. Riječje o najlakšoj te najprimjerenijoj metodi za kratkoročno ex situ očuvanje vrsta. Europski i američki pitomi kesteni najčešće su vrste obuhvaćene ovim načinom razmnožavanja (Oakes i sur. 2016a; Corredoira i sur. 2017; Gomes i sur. 2017; Vietiez i sur. 2007).

Vietiez i Vietiez (1980b) uzgojile su izdanke kestena iz postranih pupova 3-4 mjeseca starih biljaka uzgojenih in vitro. Za optimizaciju umnažanja izdanaka in vitro (Vietiez i Vietiez 1983), korištene su različite hranidbene podloge, s različitim koncentracijama iona $\mathrm{NO}_{3}^{-}$i benzilaminopurina (BAP od eng. 6-benzylaminopurine). Primjena BAP-a u koncentraciji $0,1-0,5 \mathrm{mg} / \mathrm{l} \mathrm{u}$ hranidbenoj podlozi pokazala se optimalnom za multiplikaciju zdravih izdanaka, dok je zakorjenjivanje najuspješnije potaknuto na hranidbenim podlogama s polovičnom koncentracijom iona $\mathrm{NO}_{3}{ }^{-}$od one optimalne za umnožavanje izdanaka uz dodatak IBA-e.

Miranda i Fernandez (1992) razvile su tehniku mikropropagacije koja može biti korištena u masovnoj proizvodnji genotipova kestena otpornih na tintnu bolest. Biljke uzgojene tehnikom in vitro, imale su bolji omjer podzemnog i nadzemnog dijela biljke u usporedbi s biljkama uzgojenih povaljenicama (polijeganjem).

Manje je uspješna mikropropagacija i zakorjenjivanje postranih pupova uzetih izravno iz krošnje starijih stabala. Glavni razlog tomu je fiziološka starost tkiva, odnosno mikropropagacija je uspješnija koriste li se pupovi s tkiva koje 
ima juvenilna svojstva, kao što su živići (postrani izbojci na deblima odraslih stabala) ili izdanci iz panja (Vidal i sur. 1994; Corredoira i sur. 2017).

Za razliku od europskog pitomog kestena, američki pitomi kesten znatno je teže propagirati i zakorijeniti in vitro, dok je naknadno preživljenje biljaka također smanjeno (Oakes i sur. 2016b). Autori navode kako se do $50 \%$ biljaka gubi pri svakoj fazi presadnje, odnosno prilikom presadnje na podlogu za zakorjenjivanje te u konačan supstrat za rasadnički uzgoj. Uspjeh konačne aklimatizacije u nekim je slučajevima iznosio samo $10 \%$. Kao moguće rješenje predloženo je dodavanje huminske kiseline te aktivnog ugljena u medij za zakorjenjivanje, budući da je tijekom pokusa ovaj postupak udvostručio broj razvijenih korjenčića izbojaka. Autori također navode i vermikulit kao alternativni supstrat, no nužna su dodatna istraživanja prije njegova uvođenja u praksu. Dodatan izazov primjeni vermikulita predstavlja i njegova visoka cijena.

Istraživanje somatske embriogeneze kao metode mikropropagacije pitomog kestena započelo je 80 -ih i 90-ih godina prošloga stoljeća (Vieitez i Vieitez 1980a; Vieitez i sur. 1990; Merkle i sur. 1991; Carraway i Merkle 1997). Istraženi su čimbenici koji utječu na indukciju somatskih embrija (vrsta eksplantata, uvjeti rasta, hranidbene podloge i biljni regulatori rasta), održavanje i razmnožavanje embriogenih kultura te sazrijevanje, uzgoj i aklimatizaciju kestena dobivenih somatskom embriogenezom (Corredoira i sur. 2005). Osim za propagaciju, somatska embriogeneza pitomog kestena primjenjuje se danas pri krioprezervaciji vrijednih genotipova i genskoj transformaciji pitomog kestena. Genska transformacija omogućila je dobivanje biljaka otpornih na određene patogene (Zhang i sur. 2013) uvođenjem transgena u somatske embrije (Zhang i sur. 2011; Corredoira i sur. 2016).

\section{ISKUSTVA IZ HRVATSKE EXPERIENCES FROM CROATIA}

Iako se pitomi kesten ubraja među najdugovječnije vrste jestivih plodova, organiziranog uzgoja na većim površinama u Hrvatskoj nema (Maretić 2018). Najveći se dio plodova kestena uvozi, dok se domaći plodovi, koji su najčešći na tržnicama, uglavnom sakupljaju u prirodi pa količina i kakvoća plodova varira svake godine. Pod plantažnim uzgojem maruna u Hrvatskoj nalazi se svega nekoliko desetaka hektara, najviše u Istri; veće nasade kestena nalazimo i u okolici Karlovca te Ozlja, dok se veći rasadnici za uzgoj sadnica nalaze u Rovinju, Lučkom, Topuskom, kao i u Starom Petrovom Selu.

Najznačajnije područje uzgoja u Hrvatskoj obronci su Učke, područje Lovrana, Dobreća, Lignja, Tuliševice i Lovranske Drage. Na ovome se području od davnina uzgaja tzv. lovranski marun (slika 3). Prema ranijim istraživanjima
(Idžojtić i sur. 2012), na ovome području zabilježeno je devet različitih genotipova stabala koja se vode pod nazivom lovranski marun. Ipak, glavnina uzorkovanih jedinki pripadala je jednome genotipu, odnosno kultivaru (MG01) (Ježić i sur. 2014; Poljak i sur. 2017). Ovakav rezultat govori o ciljanome razmnožavanju, odnosno cijepljenju toga kultivara.

Za razliku od plodova stabala iz prirodnih populacija, lovranski marun odlikuje se krupnim, crvenkastosmeđim i sjajnim plodovima s tamnijim i uzdužno izraženim prugama (Poljak i sur. 2016). Osim toga, plodovi lovranskog maruna slatkog su okusa, lako se čiste te najčešće sadrže samo jednu sjemenku. Iako se većina plodova prodaje na tržnicama te konzumira svježa, ove ga karakteristike čine pogodnim i za obradu (proizvodnja brašna, kandiranje) (Poljak i sur. 2021).

Maruni su i okosnica turističke ponude ovoga kraja, s Marunadom kao najznačajnijom manifestacijom u listopadu (Medak i sur. 2009). O značaju maruna na lovranskom području najbolje govori podatak kako su u 17. stoljeću, uz masline, vinovu lozu i trešnje, upravo maruni bili važan izvozni proizvod (Poljak i sur. 2016). Njihov značaj postupno se gubi zapuštanjem nasada u 20. stoljeću (Idžojtić i sur. 2012). Naime, pedesetih godina prošloga stoljeća na području Hrvatske proširila se invazivna patogena gljiva Cryphonectria parasitica, koja napada stabla pitomog kestena, a čije spore ulaze kroz rane na kori, uzrokujući rakaste tvorevine i ljuštenje kore. Nakon što micelij gljive prstenuje distalne dijelove biljke, uzrokuje odumiranje tih dijelova ili cijelih stabala. Bolest je prvi puta zabilježena upravo u okolici Lovrana 1955. godine (Kišpatić 1956), odakle se idućih godina i desetljeća proširila po cijeloj Hrvatskoj (Halambek 1986).

Lovranski marun posebno je ugrožen, jer je dokazano osjetljiviji na zarazu gljivom C. parasitica od prirodne populacije pitomog kestena iz istoga područja. Stabla lovranskog maruna teško se oporavljaju čak i u prisutnosti virusa Cryphonectria hypovirus 1 (CHV1), koji atenuira viruletnost gljive C. parasitica i oslabljuje simptome bolesti na pitomom kestenu (Ježić i sur. 2014). Ipak, u posljednjih dvadesetak godina vidljiv je trend obnove zapuštenih nasada, kao i podizanje novih.

Lovranski uzgajivači uglavnom sami cijepe svoja stabla. Pri tome neki uzgajivači cijepe tzv. talijanskim načinom, koristeći jednogodišnje plemke i jednogodišnje podloge. Drugi uzgajivači pak primjenjuju tradicionalne lovranske tehnike cijepljenja. Kao glavni razlog navode vrlo nisku stopu uspješnosti cijepljenja talijanskim načinom, od svega $5 \%$, dok je uspješnost cijepljenja tradicionalnom metodom do $100 \%$. Najuspješniji način cijepljenja je cijepljenje u raskol (slika 4), no tako cijepljene biljke iznimno su podložne razvoju raka kestenove kore na mjestu cijepa, koji predstavlja 
otvorenu ranu, podložnu za ulazak infektivnih spora gljive C. parasitica. Cijepljenje se provodi u četvrtoj godini uzgoja podloge, a prvi se plodovi dobivaju u sedmoj godini. Koristi se također i metoda cijepljenja na engleski spoj (slika 5), no postotak preživljenja biljaka je varijabilan. Osim cijepljenja plemki na mlade podloge, na području Lovrana primjenjuje se i cijepljenje na starije jedinke, odnosno kao podloge koriste se odrasla stabla. Pritom je mjesto cijepa visoko na deblu, na visini od nekoliko metara. Ovim se načinom cijepljenja revitaliziraju postojeća stabla, a iz novonastalih cijepova se razvijaju plodne grane koje su već na visini krošanja okolnih stabala.

U novije vrijeme također se sade i hibridi europskog i japanskog kestena koji, zahvaljujući otpornosti japanskog kestena, mogu preživjeti infekciju vrstama Phytophthora spp. (Pereira-Lorenzo i sur. 2010). Najčešći su 'Bouche de Betizac', koji je također otporan i na osu šiškaricu (Dryocosmus kuriphilus Yasumatsu), te 'Marsol', 'Marigoule', 'Maraval' i 'Preccoce Miguele'. Budući da se ovo svojstvo može očuvati jedino vegetativnim putem, hibridi se također razmnožavaju heterovegetativno, ksenovegetativno, transplatacijom ili cijepljenjem neotpornih (manje otpornih) plemki na otporne podloge. Neki rasadnici u Hrvatskoj cijepe ove otporne hibride na klonske podloge koje nabavljaju izravno iz europskih rasadnika. Takve su podloge također i mikorizirane (Drvodelić 2019). Najbolje rezultate postiže hibrid 'Bouche de Betizac', koji se najčešće i sadi, dok se 'Maraval', 'Marsol' i 'Precoce Migoule' sade kao oprašivači nasada. Ova su četiri hibrida i na sortnoj listi Republike Hrvatske. Prikladni oprašivači također su i kultivari 'Soutovello,' 'Almofrei,' 'Marigoule' i 'Grandiosa'. Za nasade površina od dva do deset hektara, moguće je ostvariti državne poticaje, dok je za ekološki uzgoj iznos poticaja još i veći (NN 21/2019, Pravilnik o provedbi izravne potpore poljoprivredi i IAKS mjera ruralnog razvoja za 2019. godinu).

Osim hibridnih kultivara, na području Hrvatske moguće je, preko zastupništva, uvesti i talijanske, španjolske te portugalske kultivare, mikorizirane micelijima jestivog vrganja (Boletus edulis Bull.). Prednost mikoriziranih biljaka veća je otpornost na stres u okolišu, kao i povećana otpornost na patogene. Između ostalih, moguće je nabaviti talijanske kultivare 'Hifas', 'Terra', 'Soutovello,' 'Almofrei,' 'Patron', 'Grandiosa' i 'Robusta', te portugalske i španjolske 'Judia', 'Boaventura,' 'Longal,' 'Famosa de Rios,' 'Negral del Bierzo', 'Bouche Rougue,' 'Luguesa,' 'Parede,' 'Ventura' i 'Belle Epine’.

\section{ZAKLJUČAK CONCLUSION}

Cijepljenje, uključujući okuliranje, najisplativija je metoda makropropagacije križanaca i kultivara pitomog kestena. Osim u svrhu uzgoja istovjetnih, gospodarski važnih klo- nova i križanaca za pridobivanje plodova i drva, cijepljenje se koristi i u svrhu očuvanja genskog fonda i bioraznolikosti, kao i za obnovu te očuvanje ugroženih vrsta pitomih kestena na njihovome prirodnom staništu.

Najučinkovitije tehnike cijepljenja variraju, ovisno o vrsti, kultivaru i križancu koji se cijepi, no svima je zajednička potreba za što većom genskom kompatibilnošću plemke i podloge. Osim toga, pravilna njega biljaka nakon cijepljenja od iznimne je važnosti, što uključuje ponajprije odgovarajuću temperaturu, koja osigurava uspješno kalusiranje mjesta ozljede te time srastanje kambijalnih slojeva plemke i podloge.

Uzgoj stabala maruna u Hrvatskoj također se oslanja na vegetativno razmnožavanje, ponajprije cijepljenje. Posebno je zanimljiva očuvanost tradicionalnog načina cijepljenja, koji postiže odlične rezultate te, uz pravilnu njegu mjesta cijepa, osigurava zdrave bilike. Nasadi maruna u Hrvatskoj su zbog svojeg gospodarskog, ekološkog te tradicijskog značenja vrijedna baština te ih je nužno očuvati i promovirati.

\section{ZAHVALE \\ ACKNOWLEDGEMENTS}

Rad je izrađen u okviru projekta Hrvatske zaklade za znanost (projekt IP-2018-01-1295) i hrvatsko-švicarskog istraživačkog programa koji provode Hrvatska zaklada za znanost i Švicarska nacionalna zaklada za znanost (projekt IZHRZ0_180651).

\section{LITERATURA \\ REFERENCES}

- Benković-Lačić, T., 2013: Razmnožavanje voćaka, Predavanja sa studija Bilinogojstvo, Veleučilište u Slavonskom Brodu, 44, Slavonski Brod.

- Bilderback, T., R.E. Bir, T.G. Ranney, 2014: Grafting and Budding Nursery Crop Plants, URL: https://content.ces.ncsu.edu/ grafting-and-budding-nursery-crop-plants.

- Bounous, G., 2002: Il Castano. Coltura, Ambiente ed Utilizzazioni in Italia e Nel Mondo. Edagricole, 311, Bologna.

- Bounous, G., G. Beccaro, 2002: Chestnut Culture: Directions for Establishing New Orchards, FAO-CIHEAM - Nucis-Newsletter, 11: 30-34.

- Breisch, H., 1995: Châtaignes et Marrons, CTIFL, 240, Francuska.

- Carraway, D.T., S.A. Merkle, 1997: Plantlet Regeneration from Somatic Embryos of American Chestnut, Can. J. Forest Res., 27 (11): 1805-1812.

- Carroll, B., 2017: Propagating Fruit Trees by Budding, URL: http://pods.dasnr.okstate.edu/docushare/dsweb/Get/Document-1045/HLA-6227web2014.pdf.

- Clapper, R.B, 1954: Chestnut Breeding Techniques and Results, J. Hered., 45: 107-114.

- Corredoira, E., A. Ballester, F.J. Vieitez, A.M. Vieitez, 2005: Somatic Embyogenesis in Chestnut, U: A. Mujib, J. Šamaj (ur.), 
Somatic Embyogenesis, Plant Cell Monography 2, SpringerVerlag, 177-199, Berlin Heidelberg.

- Corredoira, E., M.T. Martínez, M.J. Cernadas, M.C. San José, 2017: Application of Biotechnology in the Conservation of Genus Castanea, Forests, 10 (8): 394-408.

- Corredoira, E., M.C. San Jose, A.M. Vieitez, I. Allona, C. Aragoncillo, A. Ballester, 2016: Agrobacterium-Mediated Transformation of European Chestnut Somatic Embryos With a Castanea sativa (Mill.) Endochitinase Gene, New Forest., 47 (5): 669-684.

- Drvodelić, D., 2019: Cijepljenje sorti kestena za dobivanje visokokvalitetnog ploda (2), Gospodarski list, 178: 62-63.

- Fernandez-Lopez, J., S. Pereira, E. Miranda, 1992: Fog and Substrate Conditions for Chestnut Propagation by Leafy Cuttings, Symposium Proceedings Mass Production Technology for Genetically Improved Fast Growing Forest Tree Species, AFOCEL/ IUFRO, 379-383, Burdeos, Francuska.

- Galic, D., A. Dale, M. Alward, 2014: Vegetative Propagation of American Chestnut, Acta Hortic., 1019: 99-103.

- Gomes, F., M. Clemente, P. Figueiredo, F. Placito, H. Machado, C. Santos, R. Costa, 2017: Castanea spp. Hybrid clones in vitro conservation: synthetic seeds vs. Slow growth storage, Acta Hortic., 1155: 37-44.

- Halambek M., 1986: Chestnut blight in Yugoslavia, EPPO Bulletin 16: 533-535.

- Herman, J., 1971: Šumarska dendrologija, Stanbiro, 470, Zagreb.

- Idžojtić, M., 2013: Dendrologija cvijet, češer, plod, sjeme. Šumarski fakultet Sveučilišta u Zagrebu, 671, Zagreb.

- Idžojtić, M., M. Zebec, I. Poljak, Z. Šatović, Z. Liber, 2012: Analiza genetske raznolikosti „lovranskog maruna“ (Castanea sativa Mill.) korištenjem mikrosatelitnih biljega, Šumar. list, 136 (1112): $577-585$.

- Ježić, M., L. Krstin, I. Poljak, Z. Liber, M. Idžojtić, M. Jelić, J. Meštrović, M. Zebec, M. Ćurković-Perica, 2014: Castanea sativa: Genotype-Dependent Recovery From Chestnut Blight, Tree Genet. Genomes, 10 (1): 101-110.

- Johnson, G.P., 1988: Revision of Castanea sect. Balanocastanon (Fagaceae), J Arnold Arboretum, 69: 25-49.

- Keys, R.N., 1978: Prospects for vegetative propagation in the genus Castanea, U: W.L. Macdonald, F.C. Cech, J. Luchok, C. Smith (ur.), Proceedings of the American Chestnut Symposium, 10-17, Morgantown, West Virginia, SAD.

- Kišpatić, J., 1956: Rak kestenove kore (Endothia parasitica Anders.), Zavod za zaštitu bilja, Zagreb, Uputstva iz zaštite bilja 19: $1-12$.

- Laratta, B., F.M. Vella, L. De Masi, A. Morana, F. La Cara, 2016: Biochemical Characterization of Leaves, Burs and Shells of 'Bouche De Betizac' Chestnut Cultivar, Acta Hortic., 1242: 575580.

- Landaluce, P.V., 1952: Multiplicacion asexual de castanos, An. De Invest. Agron., 1 (2): 317-323.

- Lang, P., F. Dane, T.L. Kubisiak, 2006: Phylogeny of Castanea (Fagaceae) based on chloroplast trnT-L-F sequence data, Tree Genet. Genomes, 2 (3): 132-139.

- Maretić, M., 2018: Podizanje nasada pitomog kestena, Gospodarski list, 1: 54-55.

- Mellano, M.G., G.L. Beccaro, D. Donno, D. Torello Marinoni, P. Boccacci, S. Canterino, A. K. Cerutti, G. Bounous, 2012: Castanea spp. Biodiversity Conservation: Collection and Characterization of the Genetic Diversity of an Endangered Species, Genet. Resour. Crop Evol., 59: 1727-1741.
- Merkle, S.A., A.T. Wiecko, B.A. Watson-Pauley, 1991: Somatic Embryogenesis in American Chestnut, Can. J. Forest Res., 21 (11): 1698-1701.

- Miranda, M.E., J. Fernandez, 1992: Micropropagation as a Nursery Technique for Chestnut Hybrid Clones, U: R.D. Wallace, L.G. Spinella (ur.), Proceedings of the World Chestnut Industry Conference, 54-60, Morgantown, West Virginia, SAD.

- Maltoni, A., A. Pierguidi, P. Piussi, A. Tani, 2001: Grafting Chestnut Guide, DISTAF Universita degli Studi di Firenze, Firenca.

- Mayfeld, C., 2009: Nut-Grafting, URL:https://www.acf.org/wpcontent/uploads/2016/09/Mayfeld-Nut-Grafting-Mar-07.pdf.

- Medak, J., M. Idžojtić, S. Novak-Agbaba, M. Ćurković-Perica, I. Mujić, I. Poljak, D. Juretić, Ž. Prgomet, 2009: Croatia. Following Chestnut Footprints (Castanea spp.) - Cultivation and Culture, Folklore and History, Traditions and Use, U: D. Avanzato (ur.), Scripta Horticulture, 9: 40-43.

- Mudge, K., J. Janick, S. Scofield, E.E. Goldschmidt, 2009: A History of Grafting, Horticultural Reviews, Volume 35, John Wiley \& Sons, Inc., 437-493, Hoboken.

- Moore, J.C., 1963: Propagation of Chestnuts and Camellia by Nurse Seed Grafts, Int. Plant Prop. Soc., 13: 141-143.

- Nelson, C.D., W.A. Powell, S.A. Merkle, J.E. Carlson, F.V. Hebard, N. Islam-Faridi, M.E. Staton, L. Georgi, 2014: Biotechnology of Trees: Chestnut, Biology and Biotechnology, 2-35.

- Oakes, A.D., T.R. Desmarais, W.A. Powell, C.A. Maynard, 2016a: Ex vitro Rooting of American Chestnut Improves Acclimatization Survival and Plantlet Quality, J. Environ. Hortic., 34 (3): 75-79.

- Oakes, A.D., T.R. Desmarais, W.A. Powell, C.A. Maynard, 2016b: Improving Rooting and Shoot Tip Survival of Micropropagated Transgenic American Chestnut Shoots, Hortic. Sci., 51 (2): 171-176.

- Oraguzie, N., A.M. Paterson, D. McNeil, 1999: Origin and Relationships of New Zealand Chestnut (Castanea sp., Fagaceae) Selections Reflect Patterns Of Graft Failure, Plant Syst. Evol., 218 (3): 193-204.

- Pereira-Lorenzo, S., R.M.L. Costa, A.M. Ramos-Cabrer, C.A. Marques Ribeiro, M.F. Serra da Silva, G. Mazano, T. Barreneche, 2010: Variation in Grafted European Chestnut and Hybrids by Microsatellites Reveals Two Main Origins in the Iberian Peninsula, Tree Genet. Genomes, 6(5): 701-715.

- Pereira-Lorenzo, S., J. Fernandez-Lopez, 1997: Propagation of Chestnut Cultivars by Grafting: Methods, Rootstocks and Plant Quality, J. Hortic. Science, 72 (5): 731-739.

- Poljak, I., 2014: Morfološka i genetska raznolikost populacija i kemijski sastav plodova europskog pitomog kestena (Castanea sativa Mill.) u Hrvatskoj, Doktorski rad, Šumarski fakultet Sveučilišta u Zagrebu, 231, Zagreb.

- Poljak, I., M. Idžojtić, Z. Šatović, M. Ježić, M. Ćurković Perica, B. Simovski, J. Acevski, Z. Liber, 2017: Genetic Diversity of the Sweet Chestnut (Castanea sativa Mill.) in Central Europe and the Western Part of the Balkan Peninsula, and Evidence of Marron Genotype Introgression Into Wild Populations, Tree Genet. Genomes, 13: 18.

- Poljak, I., N. Vahčić, M. Gačić, M. Idžojtić, 2016: Morphological Characterization and Chemical Composition of Fruits of the Traditional Croatian Chestnut Variety 'Lovran Marron', Food Technol Biotechn., 54 (2): 189-199.

- Poljak, I., N. Vahčić, M. Gačić, A. Vidaković, K. Tumpa, I. Žarković, M. Idžojtić, 2021: Traditional Sweet Chestnut and 
Hybrid Varieties: Chemical Composition, Morphometric and Qualitative Nut Characteristics, Agronomy, 11 (3): 516.

- Pravilnik o provedbi izravne potpore poljoprivredi i IAKS mjera ruralnog razvoja za 2019. godinu (NN 21/2019).

- Relf, D., E. Ball, 2009: Propagation by Cuttings, Layering and Division, Virginia Cooperative Extension, 6, Petersburg, Virginia, SAD.

- Rothenberger, R.R., C.J. Starbuck, 2008: Horticultural MU Guide - Grafting, University of Missouri Extension, 8, Columbia, Missouri, SAD.

- Serdar, U., A. Soylu, 2005: The Effect of Grafting Time and Methods on Chestnut Nursery Tree, Acta. Hort 693: 187-194.

- Singh, S.R., M.U. Rehman, 2019: Castanea, U: S.N. Ghosh, A. Kumar (ur.), Cultivate Minor Temperate Fruits Scientifically, Part 1., Jaya Publishing House, 567, Delhi, Indija.

- Vidal, N., A. Ballester, A.M. Vietiez, C. Kevers, Th. Caspar, 1994: Biochemical characteristics of chestnut shoots related to in vitro multiplication and rooting capacities, Adv. Hort. Sci., 8: 19-24.

- Vietiez, E., 1953: Estudios sobre la reproduccion vegetativa del castano. i. enraizamiento en el acodo alto mediante el empleo de fitohormonas, An. de Edafol. Y Fisio. Veg., 12 (4): 337-373.

- Vietiez, E., E. Seoane, M.D.V. Gesto, J. Mendez, M.C. Mato, A. Vazquez, 1955: El empleo de sustancias de accion hormonal en el enraizamiento del castano por acodo bajo, An. de Edafol. Y Fisio. Veg., 14 (9/10): 483-518.

- Vietiez, E., E. Seoane, M.D.V. Gesto, J. Mendez, M.C. Mato, A. Vazquez, 1964: The First Steps in the Isolation of Plant Hor- mones Associated With the Rooting Capacity of the Woody Cuttings, An. de Edatol. Y Agrobiol., 23 (11/12): 777-798.

- Vietiez, A.M., M.C. Sanchez, M.L. Garcia-Nimo, A. Ballester, 2007: Protocol for Micropropagation of Castanea sativa, Protocols for Micropropagation of Woody Trees and Fruits, Springer Books, 559, Berlin.

- Vieitez, F.J., M.C. San-José, A. Ballester, A.M. Vieitez, 1990: Somatic Embryogenesis in Cultured Immature Zygotic Embryos in Chestnut, J. Plant Physiol., 136: 253-256.

- Vieitez, A.M., E. Vieitez, 1983: Castanea sativa plantlets proliferated from axillary buds cultivated in vitro, Sci. Hortic., 18 (4): 343-351.

- Vieitez, A.M., E. Vieitez, 1980a: Plantlet Formation from Embryogenic Tissue of Chestnut Grown in vitro, Physiol. Plantarum, 50: 127-130.

- Vieitez, A.M., M.L. Vieitez, 1980b: Culture of chestnut shoots from buds in vitro, J. Hortic. Sci., 55: 83-84.

- Zhang, B., A. Newhouse, L. McGuigan, C. Maynard, W. Powell, 2011: Agrobacterium-Mediated Co-transformation of American Chestnut (Castanea dentata) Somatic Embryos with a Wheat Oxalate Oxidase Gene, BMC Proc 5 (Suppl 7): 043.

- Zhang, B., A.D. Oakes, A.E. Newhouse, K.M. Baier, C.A. Maynard, W.A. Powell, 2013: A Threshold Level of Oxalate Oxidase Transgene Expression Reduces Cryphonectria parasitica-Induced Necrosis in a Transgenic American Chestnut (Castanea dentata) Leaf Bioassay, Transgenic Res., 22:973nsge.

\section{SUMMARY}

Selected varieties of sweet chestnut called marrons are cultivated for their large and exquisite fruits. Most of the countries with native sweet chestnut populations have their autochthonous varieties that were arduously created through selective breeding over many centuries. Marron cultivation has a long history in Croatia, mostly in the Lovran area and its surroundings. Although threatened by pests and diseases, as well as land abandonment, some growers still practice the traditional cultivation methods. This paper provides an overview of the most common vegetative propagation methods utilized for the sweet chestnut and marrons sapling production, as well as a shorter overview of cultivation methods, breeding, and the importance of marron plantations in Croatia. Identical fruit characteristics can be inherited by progenies only through faithful passing on of the parent's genotype, thus marrons are propagated vegetatively. Grafting is the most common method of vegetative propagation of marrons in tree nurseries. Other vegetative methods discussed are propagation by layering, cuttings and tissue culture, occasionally used in the reproduction of sweet chestnut.

KEY WORDS: vegetative propagation, grafting, marrons, sweet chestnut, varieties 